THE BURDEN OF UNEMPLOYMENT ON FAMILY UNITS: AN OVERVIEW*

by

Paul W. Miller

Department of Economics

The University of Western Australia

* This research was supported by a grant from the Australian Research Council. I am grateful to Leanne Neo for research assistance and to two referees for helpful comments. 


\title{
THE BURDEN OF UNEMPLOYMENT ON FAMILY UNITS: AN OVERVIEW
}

\begin{abstract}
This paper proposes several measures of the burden of unemployment on family units. It is shown that one in 13 couple families had at least the husband or wife unemployed in 1994. Almost one-quarter of the total unemployment among couple families in 1994 was in families where both husband and wife were unemployed. The analyses presented show that the burden of unemployment on family units differs according to the characteristics of the family. It is particularly intense in couple families with young dependants and among immigrants from non-English-speaking countries. Of particular concern is the finding that there are many families where there are multiple family members unemployed and no member employed. This will have major implications where knowledge of employment opportunities is obtained primarily through family contacts.
\end{abstract}


THE BURDEN OF UNEMPLOYMENT ON FAMILY UNITS: AN OVERVIEW

\section{INTRODUCTION}

The problem of unemployment in Australia has occupied the minds of economic and social researchers and policy makers since the mid-1970s when there was a sudden upward jump in the unemployment rate. Prior to 1974-75 the unemployment rate in Australia rarely exceeded the conventional definition of full employment. In 1974-75, however, the unemployment rate broke through the 4 per cent barrier, and since then many commentators have doubted whether the Australian economy would ever return to full employment. There have been periods of "economic sunshine", though these have not been sustained. For example, the unemployment rate was around 4 per cent in 1981 before it rose sharply to around 10 per cent in 1983. It fell below 6 per cent in 1990 before returning to double-digit levels in 1992.

A number of economists have sought to explain the growth in aggregate unemployment through reference to theories of real wage growth and stagnation in world economies [e.g., Russell and Tease (1991)]. Other economists have taken the aggregate unemployment situation as given and have examined the extent to which unemployment impacts differentially on various members of society [e.g., Inglis and Stromback (1986)]. The latter line of research demonstrates that better educated, prime-aged Australian-born labour force participants have lower unemployment rates than other groups. Within this strand of research there have been a number of examinations of the links between the labour market status of members of family units [see, for example, Bradbury et al. (1986), Bureau of Labour Market Research (1986), King et al. (1995), Miller and Volker (1987)]. These studies show that there is a strong similarity between the labour market status of partners. For example, in Miller and Volker's study of youth based on the 1985 Australian Longitudinal Survey it is reported that the predicted unemployment rate of a married male with an unemployed partner is 33 percentage points higher than for other married groups. This finding is representative of studies of unemployment that adopt a family perspective, and is indicative of a concentration of the burden of unemployment in particular households. 
The aim of this overview paper is to examine in detail the concentration of the burden of unemployment in particular households and to establish research priorities in this regard. Three basic sets of questions are asked. First, is unemployment concentrated in particular family units? Second, has this concentration changed over time? In other words, is the degree of inequality in this regard intensifying as it is with many other indicators of economic well being in Australian society [see, for example, Borland and Wilkins (1996)]. Third, are some family groups more prone to having multiple members unemployed than others?

Given these research questions, it is apparent that the research conducted here has much in common with recent work by Gregory and Hunter (1995) (1996) and Harding (1996). Gregory and Hunter (1995), for example, provide a detailed examination of income inequality and dispersion of economic opportunities across urban neighbourhoods. They show that since the early 1970s there has been increased economic polarisation within our cities, with low socio-economic status areas being characterised by job loss and income falls, and high socio-economic status areas being characterised by job growth and income rises. The impact of these broad patterns of job creation and loss on the family unit is examined in detail in this study.

The structure of the paper is as follows. In Section II several alternative ways of measuring the burden of unemployment are considered, and changes in the concentration of the burden of unemployment over time are examined. In Section III labour market data from 1985 and 1994 are examined in detail to develop an understanding of the changes in the concentration of unemployment. The effects of characteristics of the family on the burden of unemployment are examined in Section IV. Section V considers the sensitivity of the findings to the data source used, and extends the analysis to family members other than spouses. Section VI provides a conclusion and includes possible directions for future research. 


\section{THE CHANGING BURDEN OF UNEMPLOYMENT}

One in 13 couple families had at least the husband or wife unemployed in 1994. Almost one-quarter of the total unemployment among couple families in 1994 was in families where both husband and wife were unemployed.

One of the most commonly quoted statistics in Australia is the unemployment rate. This is defined as the percentage of a particular group of labour force participants that is unemployed. It is generally advanced as a measure of economic hardship. From the perspective of the family unit, however, the unemployment rate may not be the most informative measure of the economic and social impact of a given level of joblessness.

Consider a situation where there are 100 couple families, all family members are labour force participants, and the aggregate unemployment rate is 10 per cent. In one scenario the 20 people who are unemployed are located in 20 different families. In another the 20 unemployed persons are concentrated in 10 families. In the latter case the burden of unemployment might be considered a more pressing problem due to the intensity with which it impacts on one section of the population. It might also be a more pressing problem to the extent that unemployed persons reinforce negative behaviours if concentrated together, and where employment tends to be found via informal networks involving employed family members.

How can the burden of unemployment on the family unit be assessed? A number of measures are possible. First, one can compute the percentage of the total unemployment among couple families that occurs in families where both husband and wife are unemployed. In the two extremes outlined above, this ranges from 0 to 100 per cent. Second, the fraction of couple families where at least one spouse is unemployed can be computed to give a measure of economic hardship. Third, the fraction of couple families where both spouses are unemployed can also be determined and this will provide a measure of more acute hardship than the previous calculation. It is informative to express these incidence data in terms of the ratio of all couple families to families that satisfy the particular criterion. For example, one couple family in 20 might have at least one spouse unemployed, and one couple family in 200 might have both spouses unemployed. 
Data on the concentration of the burden of unemployment on the family unit can be obtained from several sources, and the unemployment situation described appears to be data dependent. The two sources used in this study are the Australian Bureau of Statistics' (ABS) publication Labour Force Status and Other Characteristics of Families and the 1991 Census of Population and Housing. The Labour Force Status and Other Characteristics of Families is based on the Labour Force Survey and comprises a sample of households in occupied private dwellings, the members of which were aged 15 and over and were residents of Australia. It accounts for about one-half of one per cent of the population in Australia. Extensive information regarding the labour force status of individuals in different family types was collected. The sample excludes families where at least one member was living in a non-private dwelling. Families which include a member of the permanent defence forces were also excluded. The information from the 1991 Census used in this study is extracted from the Household Sample File produced by the ABS. A crucial difference between the two data sources is that labour force status in the 1991 Census is self-enumerated, whereas the Labour Force Survey that forms the basis for the Labour Force Status and Other Characteristics of Families is interview based. The number of unemployed in the Census exceeds that in the comparable Labour Force Survey by 9 per cent (ABS, 1994a). This may be due to the under-reporting of jobs involving only a few hours in the Census. Such an occurrence might reasonably be expected to lead to greater similarity of labour market outcomes in the family unit.

Table 1 lists data derived from the Labour Force Survey on the aggregate male unemployment rate and the three measures of the burden of unemployment for each year between 1979 and $1994 .^{1}$

\footnotetext{
${ }^{1}$ In both the Labour Force Status and Other Characteristics of Families data set and the 1991 Census of Population and Housing, couple families include those in de facto relationships.
} 
Table 1: Male Unemployment Rates and the Measures of the Burden of Unemployment on Family Units, Ages 15 and Over, 1979 - 1994

\begin{tabular}{|c|c|c|c|c|}
\hline \multirow[t]{2}{*}{ Year } & \multirow{2}{*}{$\begin{array}{c}\text { Male } \\
\text { Unemployment } \\
\text { Rate } \\
\%\end{array}$} & \multirow{2}{*}{$\begin{array}{c}\% \text { of Unemployment in } \\
\text { Couple Families where } \\
\text { Husband \& Wife were } \\
\text { Both Unemployed }\end{array}$} & \multicolumn{2}{|c|}{$\begin{array}{l}\text { Number of Families per Couple Family with } \\
\text { Unemployed Spouse, where the Family has: }\end{array}$} \\
\hline & & & $\begin{array}{l}\text { At Least One Spouse } \\
\text { Unemployed }\end{array}$ & $\begin{array}{l}\text { Both Husband and Wife } \\
\text { Unemployed }\end{array}$ \\
\hline (i) & (ii) & (iii) & (iv) & (v) \\
\hline 1979 & 5.0 & 8.64 & 27.11 & 600.29 \\
\hline 1980 & 5.0 & 13.08 & 27.55 & 393.86 \\
\hline 1981 & 4.3 & 12.45 & 28.48 & 429.08 \\
\hline 1982 & 5.6 & 11.04 & 22.51 & 385.16 \\
\hline 1983 & 9.8 & 18.20 & 13.95 & 139.40 \\
\hline 1984 & 8.5 & 18.00 & 17.18 & 173.75 \\
\hline 1985 & 8.2 & 15.50 & 17.61 & 209.67 \\
\hline 1986 & 7.0 & 18.12 & 17.92 & 179.84 \\
\hline 1987 & 7.6 & 17.78 & 17.13 & 175.78 \\
\hline 1988 & 6.7 & 15.43 & 18.10 & 216.58 \\
\hline 1989 & 5.4 & 17.90 & 21.19 & 215.55 \\
\hline 1990 & 6.0 & 17.62 & 20.34 & 210.62 \\
\hline 1991 & 9.3 & 19.86 & 14.19 & 128.74 \\
\hline 1992 & 11.2 & 22.52 & 11.96 & 94.24 \\
\hline 1993 & 11.3 & 22.93 & 12.00 & 92.66 \\
\hline 1994 & 9.9 & 23.81 & 12.96 & 95.87 \\
\hline
\end{tabular}

Source: ABS, Labour Force Status and Other Characteristics of Families, 1979 - 1994, and ABS, The Labour Force, 1979 -1994.

Note: Column (iii) is the percentage of the total unemployment among couple families that occurs where both husband and wife were unemployed. This is termed Measure \#1 in the text.

Column (iv) lists the average number of all couple families per couple family where at least one spouse was unemployed. This is termed Measure \#2 in the text.

Column (v) lists the average number of all couple families per couple family where both husband and wife were unemployed. This is termed Measure \#3 in the text.

The Table 1 data reveal that conditions in the Australian labour market have deteriorated markedly between 1979 and 1994 . Thus, the male unemployment rate increased by 4.4 per cent each year, ${ }^{2}$ and approximately doubled over the 15 year period under review. Of the three measures of the

\footnotetext{
${ }^{2}$ Growth rates in this section have been computed from a simple regression of the natural logarithm of the specific measure of unemployment on a linear time trend. The $\mathrm{R}^{2} \mathrm{~s}$ in these regressions are as high as 0.75 .
} 
burden of unemployment on the family unit, the most general is the second measure, which records the ratio of all couple families to couple families with at least one spouse unemployed. This measure changed from around 27 to 13 . This is equivalent to a decay of almost five per cent each year, which parallels the changes in the male unemployment rate. In percentage terms, the measure has, like the male unemployment rate, doubled, from 3.7 per cent to 7.7 per cent. ${ }^{3}$ However, when the burden of unemployment measure has a sharper focus on couple families where both husband and wife are unemployed, a more troublesome picture emerges. Hence, whereas only 8.64 per cent of all unemployment experienced by couple families in 1974 was in couple families where both husband and wife were unemployed, by 1994 this figure had risen three-fold, to 23.81 per cent (see Measure \#1).

This situation may be examined from an alternative perspective using the third measure of the burden of unemployment. This measure shows that while situations where both husband and wife were unemployed were quite rare in the 1970s (only one family in 600 in 1979), by the 1990s this had become a reasonably common feature of society, with one couple family in 100 having both spouses unemployed. The latter measure has declined at 10 per cent per year. ${ }^{4}$

Unemployment, therefore, is becoming more concentrated in family units. It is suggested, therefore, that given this concentration, any given level of unemployment now poses a much more serious social and economic problem than previously. The analyses presented in the following section attempt to discover how this problem has evolved.

\footnotetext{
${ }^{3}$ The per cent of all couple families where at least one spouse is unemployed is the reciprocal of the second measure times 100 . Thus, $1 / 27.11 \times 100=3.7$ per cent, and $1 / 12.96 \times 100=7.7$ per cent.

${ }^{4}$ All three measures of the concentration of unemployment are highly correlated with the indicator of the state of the economy provided by the male unemployment rate, with the simple correlation coefficients between the male unemployment rate and the three measures of the burden of unemployment being, respectively, $0.84,0.94$ and 0.81 . The elasticity of measure $\# 3$ with respect to the male unemployment rate, computed from a logarithmic regression model, exceeds one in absolute value. In comparison, the elasticity of measure \#2 with respect to the male unemployment rate is less than one in absolute value.
} 


\section{THE DISTRIBUTION OF COUPLE FAMILIES ACROSS LABOUR MARKET STATES}

Changes in the male labour market may have played a major role in increasing the concentration of the burden of unemployment in couple families.

In order to highlight the major changes that have taken place in the Australian labour market in recent years, detailed information from the Labour Force Status and Other Characteristics of Families is presented for two years, 1985 and 1994. Then data from the 1991 Australian Census are discussed.

Table 2 lists data for 'couple families' where the labour force status of the wife in 1985 has been cross-classified by that of the husband in the same year. The first row of this table gives the distribution across labour force states of married women whose husbands were employed on a fulltime basis. According to these data, 53.8 per cent of married women with husbands working full time were employed on either a full-time (28.4 per cent) or part-time (25.4 per cent) basis. A further 2.5 per cent of the married women whose husbands were working full time were unemployed. This means that their labour force participation rate was 56.3 per cent in 1985 and their unemployment rate was only 4.4 per cent.

Table 2: Couple Families: Labour Force Status of Husband and Wife, Ages 15 and Over, July 1985, Numbers ('000 families) and Per cent Distribution

\begin{tabular}{|c|c|c|c|c|c|c|}
\hline Wife & $\begin{array}{c}\text { Employed } \\
\text { Full time }\end{array}$ & $\begin{array}{c}\text { Employed } \\
\text { Part time }\end{array}$ & Unemployed & $\begin{array}{c}\text { Not in the } \\
\text { labour force }\end{array}$ & $\begin{array}{c}\text { All labour } \\
\text { force states }\end{array}$ & $\begin{array}{c}\text { Wife's } \\
\text { Unemploy. } \\
\text { rate }\end{array}$ \\
\hline $\begin{array}{c}\text { Employed } \\
\text { Full time }\end{array}$ & $28.4 \%$ & $25.4 \%$ & $2.5 \%$ & $43.7 \%$ & $\begin{array}{c}100 \% \\
2530.3\end{array}$ & $4.4 \%$ \\
\hline $\begin{array}{c}\text { Employed } \\
\text { Part time }\end{array}$ & $18.8 \%$ & $25.7 \%$ & $3.0 \%$ & $52.5 \%$ & $100 \%$ & $6.4 \%$ \\
\hline $\begin{array}{c}\text { Unemployed } \\
\text { Not in the }\end{array}$ & $8.8 \%$ & $6.4 \%$ & $13.0 \%$ & $71.8 \%$ & $100 \%$ & $46.0 \%$ \\
\hline $\begin{array}{c}\text { All labour } \\
\text { force states }\end{array}$ & $7.0 \%$ & $3.3 \%$ & $0.5 \%$ & $91.2 \%$ & $100 \%$ & $5.8 \%$ \\
\hline $\begin{array}{c}\text { Husband's } \\
\text { Unemploy. } \\
\text { rate }\end{array}$ & $1.5 \%$ & $20.1 \%$ & $2.5 \%$ & $54.9 \%$ & $100 \%$ & $5.50 \%$ \\
\hline
\end{tabular}

Source: ABS, Labour Force Status and Other Characteristics of Families, July 1985 
At the 1985 survey, 44.5 per cent of married women with spouses working part time were employed, and slightly more than half (about 58 per cent) of these women worked part time. Three per cent of this group were unemployed. Accordingly, 47.5 per cent of married women with spouses working part time were in the labour force, and their unemployment rate was 6.4 per cent. The attachment of this group to the labour force, therefore, is marginally less than that of the wives of men in full-time employment.

The third row of data in Table 2 relates to women whose husbands were unemployed. In contrast to the first two rows of data relating to the distributions across labour market states for women whose husbands were employed, relatively few women with unemployed husbands are employed. Thus the Table 2 data show that only 15.2 per cent of this group are employed. However, a striking 13 per cent are unemployed. Hence for this group the labour force participation rate is only 28.2 per cent and the unemployment rate is an imposing 46 per cent. This is almost nine times the rate of unemployment for all married women in couple families (see row five). ${ }^{5}$

The labour market status of couple families where the husband is not in the labour force is characterised by a high percentage of wives being non-participants. In particular, only 8.8 per cent of these women were in the labour force, while there is a negligible representation of this group in the unemployment state $(0.5$ per cent).

The data in Table 2 therefore reveal an apparent relationship between a married woman's labour force status and that of her husband. Amongst these married women, those with husbands working full time have the highest labour force participation rate. This is followed (in terms of labour force participation rate) by married women with husbands working part time. The labour force participation rate is lowest among those married women whose husbands are non-participants. In terms of unemployment, the data reveal that the unemployment rate is greatest among those married

\footnotetext{
${ }^{5}$ King et al. (1995) argue that there are several direct effects of the husband's unemployment on the wife's labour force status, including the disincentives caused by income testing in the welfare system, what King et al. refer to as "bruised machismo" effects, and the added worker effect due to the need to supplement family income.
} 
women whose husbands are unemployed, and lowest among women whose husbands work on a fulltime basis. The unemployment rates of these two groups differ by a factor of ten, and this serves to highlight the inequality in the distribution of unemployment in the labour market.

The above discussion has been from the perspective of male chauvinist models of the labour market in that it has conditioned on the labour market status of the husband. It is interesting for the purposes of discussion to reverse the standing of husband and wife in this regard and condition on the wife's labour market status. This discussion will, however, be confined to the unemployment rate. Hence we see from the final row of Table 2 that the labour force status of the wife has a significant impact on the husband's unemployment rate. Married men with an unemployed spouse experienced an unemployment rate of about 20 per cent. In contrast, married men with spouses employed full time or part time faced unemployment rates of 1.5 per cent and 1.2 per cent respectively. Thus the unemployment rates among the groups having the highest and lowest rates differ by a factor of 17 , a differential that is again indicative of inequality in the distribution of unemployment in the Australian labour market.

Table 3: Couple families: Labour Force Status of Husband and Wife, Ages 15 and Over, June 1994, Numbers ('000 families) and Per cent Distribution

\begin{tabular}{|c|c|c|c|c|c|c|}
\hline $\begin{array}{c}\text { Wife } \\
\text { Husband }\end{array}$ & $\begin{array}{l}\text { Employed } \\
\text { Full time }\end{array}$ & $\begin{array}{l}\text { Employed } \\
\text { Part time }\end{array}$ & Unemployed & $\begin{array}{l}\text { Not in the } \\
\text { labour force }\end{array}$ & $\begin{array}{l}\text { All labour } \\
\text { force states }\end{array}$ & $\begin{array}{c}\text { Wife's } \\
\text { Unemploy. } \\
\text { rate }\end{array}$ \\
\hline $\begin{array}{l}\text { Employed } \\
\text { Full time }\end{array}$ & $35.8 \%$ & $30.3 \%$ & $2.8 \%$ & $31.0 \%$ & $\begin{array}{c}100 \% \\
2677.8\end{array}$ & $4.1 \%$ \\
\hline $\begin{array}{l}\text { Employed } \\
\text { Part time }\end{array}$ & $24.1 \%$ & $29.8 \%$ & $4.5 \%$ & $41.7 \%$ & $\begin{array}{l}100 \% \\
166.7 \\
\end{array}$ & $7.7 \%$ \\
\hline Unemployed & $12.5 \%$ & $11.9 \%$ & $19.2 \%$ & $56.3 \%$ & $\begin{array}{l}100 \% \\
216.7 \\
\end{array}$ & $44.1 \%$ \\
\hline $\begin{array}{l}\text { Not in the } \\
\text { labour force }\end{array}$ & $6.1 \%$ & $5.4 \%$ & $0.9 \%$ & $87.6 \%$ & $\begin{array}{l}100 \% \\
936.7 \\
\end{array}$ & $7.14 \%$ \\
\hline $\begin{array}{l}\text { All labour } \\
\text { force states }\end{array}$ & $\begin{array}{l}27.1 \% \\
1084.4 \\
\end{array}$ & $\begin{array}{c}23.4 \% \\
937.0 \\
\end{array}$ & $\begin{array}{l}3.3 \% \\
133.5 \\
\end{array}$ & $\begin{array}{l}46.1 \% \\
1843.0 \\
\end{array}$ & $\begin{array}{c}100 \% \\
3997.9 \\
\end{array}$ & $6.2 \%$ \\
\hline $\begin{array}{c}\text { Husband's } \\
\text { Unemploy. } \\
\text { rate }\end{array}$ & $2.6 \%$ & $2.9 \%$ & $33.3 \%$ & $11.9 \%$ & $7.1 \%$ & \\
\hline
\end{tabular}

Source: ABS, Labour Force Status and Other Characteristics of Families, June 1994 
Table 3 presents data for the labour force status of both the husband and the wife in couple families in 1994. Reading down the diagonals (which represent like labour force states) of Tables 2 and 3, it is seen that the percentage representations are greater in 1994 in all cases other than for nonparticipants. One consequence of this greater similarity in labour market outcomes is that the concentration of the burden of unemployment in the family unit has increased, as reported in Table 1. Comparison of the data in Tables 2 and 3 also indicates that the labour force activity of married women has changed considerably over recent decades. In aggregate their labour force participation rate has increased by almost nine percentage points, from 45.1 per cent to 53.9 per cent.

It is also apparent that the labour force participation rates of married women have increased regardless of the husband's labour force status, though the greatest increase in this regard has been among married women with unemployed husbands. For this group the labour force participation rate grew by 15.4 percentage points. For married women with husbands working full time or part time, the increases in the participation rate were 12.6 percentage points and 10.8 percentage points respectively. The participation rate of those women whose husbands were not in the labour force, however, grew by only 3.6 percentage points over the decade under review.

The proportion of married women reported as unemployed increased over the period. For all married women the increase in representation in the state of unemployment has been from 2.5 per cent to 3.3 per cent, an increase of 32 per cent. This increase, however, has not been spread evenly across all groups, with the proportion of unemployed married women having increased by between 14 per cent and 74 per cent across the various groups of married women over the past decade. For example, 2.8 per cent of married women whose husbands were employed on a full-time basis were unemployed in 1994 compared with 2.5 per cent in 1985 - a modest increase. However, 19.2 per cent of married women with unemployed husbands were unemployed in 1994, as compared to 13 per cent in 1985 (a 48 per cent increase).

With the higher levels of labour force participation, however, the higher numerical representation in the unemployed state among some groups of females does not necessarily translate 
into higher unemployment rates. In particular, the unemployment rate of wives where the husband was employed on a full-time basis has declined marginally over the period under review (from 4.4 per cent to 4.1 per cent), as has the unemployment rate of wives whose husband were unemployed (from 46 per cent to 44.1 per cent). In comparison, the unemployment rates of wives where the husband was employed on a part-time basis or was not in the labour force have each increased by about 1.3 percentage points. Across all labour force states of the husband, the unemployment rate of married women increased by 13 per cent between 1985 and 1994, from 5.5 per cent to 6.2 per cent.

Married men also face a higher unemployment rate in the 1990s, with their unemployment rate having increased from 4.6 per cent to 7.1 per cent between 1985 and $1994 .{ }^{6}$ The proportionate increase in unemployment over the decade under review has been strongest for those with spouses working part time (which rose by 140.5 per cent over the period). There was also a 66 per cent (a rise from 20.1 per cent to 33.3 per cent) increase in the unemployment rate among married men with unemployed spouses. This increase will serve to intensify the concentration of the burden of unemployment. It also suggests that changes in the male labour market may have played a major role in increasing the concentration of the burden of unemployment in couple families.

\section{THE EFFECTS OF CHARACTERISTICS OF THE FAMILY ON THE BURDEN OF UNEMPLOYMENT}

For immigrants from non-English-speaking countries, one couple family in every 8 has either the husband or wife unemployed. For this group unemployment is an obvious major social problem. Moreover, one couple family in every 48 has both the husband and wife unemployed, indicating a considerable degree of concentration of the burden of unemployment.

\footnotetext{
${ }^{6}$ Whether this shows a more substantial deterioration of the job market for males than for females is debatable. Due to the "grey" boundaries between the not-in-the-labour force and unemployed states, the unemployment rate is typically viewed as a questionable indicator of the state of the labour market for married women. An alternative indicator is employment growth. Total employment grew between 1985 and 1994 by 36 per cent for married women in couple families, and by 8 per cent for their male counterparts. These data also suggest that conditions in the male labour market were less prosperous.
} 
The data in Tables 1, 2 and 3 show, therefore, that unemployment is concentrated within couple families. It is well known that the incidence of unemployment varies according to the characteristics (age, educational attainment etc.) of individuals, and that there is assortative mating in marriage. Accordingly, it might be expected that the burden of unemployment will vary across couple families distinguished on the basis of their birthplace, age, race and family status. In this regard, the ABS publication Labour Force Status and Other Characteristics of Families permits insights into the influence on labour market outcomes of a number of additional characteristics such as birthplace, age of the wife and age of the youngest dependant child. Table 4 contains summary details relevant to the concentration of unemployment issue.

Table 4: Measures of the Burden of Unemployment in Couple Families, Ages 15 and Over, by Selected Characteristics, 1994

\begin{tabular}{|c|c|c|c|}
\hline \multirow{2}{*}{ Characteristics } & \multicolumn{2}{|c|}{ Burden of Unemployment } \\
\hline $\begin{array}{c}\text { Dependent Children } \\
\text { without dependants }\end{array}$ & Measure \#1 & 17.89 & Measure \#3 \\
with dependants & 25.97 & 10.07 & 19.88 \\
\hline Age of Youngest Dependent & 22.53 & & 79.36 \\
$0-4$ & 19.24 & 8.39 & 78.83 \\
$5-9$ & 28.73 & 9.88 & 58.87 \\
$10-14$ & 25.79 & 11.12 & 75.09 \\
$15-24$ & 15.49 & 10.69 & 79.36 \\
Total & 22.53 & 14.96 & 127.25 \\
born in Australia & 21.04 & 9.83 & 60.19 \\
born Overseas & 28.08 & 14.02 & 98.13 \\
$\quad$ English-speaking & & & 47.97 \\
country & 25.00 & 8.22 & \\
\hline non-English-speaking & & & \\
\hline
\end{tabular}

For notes to Table, see Table 1.

The data presented in Table 4 reveal that approximately one couple family in 18 where there are no dependent children has either the husband or wife unemployed. However, where there are dependants, this ratio is a striking one family in 10. Moreover, among couple families with dependants, approximately one in 80 couple families has both husband and wife unemployed. Among couple families without dependants the situation is that approximately one in 120 couple families has 
both husband and wife unemployed. In each case, around one-quarter of the total unemployment is concentrated in couple families where both spouses are unemployed.

With respect to families with dependent children, the data reveal a dichotomy between couples with at least one child younger than 15 and those where the youngest child is 15 years or older. In the case of the latter group, about one family in 21 has at least one spouse unemployed, and one family in approximately 250 has both spouses unemployed. Only 15 per cent of the total unemployment is concentrated in families where both husband and wife are unemployed. Among the other families represented in Table 4, however, the unemployment situation is much more serious. Consider couple families whose youngest child is aged between 5 and 9. For this group one family in every 10 has at least one spouse unemployed. 29 per cent of the total unemployment for this group is concentrated in couple families where both husband and wife are unemployed.

While the differences in the burden of unemployment between families with and without dependants may be the cause for concern, the differences across birthplace groups seems to even more pressing. In the case of the Australian born, one couple family in every 15 has at least one spouse unemployed, and both husband and wife are unemployed in one in every 127 couple families. 21 per cent of all unemployment occurs in couple families where both husband and wife are unemployed. The figures for immigrants from English-speaking countries are similar to those for the Australian born. Thus one couple family in every 14 has at least one spouse unemployed and one couple family in every 98 has both the husband and wife unemployed. One-quarter of the total unemployment is concentrated in couple families where both spouses are unemployed. The unemployment situation from the family perspective is, however, a far greater problem for immigrants from non-Englishspeaking countries. Thus, for this group one couple family in every 8 has at least the husband or wife unemployed. One couple family in every 48 has both the husband and wife unemployed. Thirty per cent of the total unemployment for this group is concentrated in family units where both spouses are unemployed. $^{7}$

\footnotetext{
${ }^{7}$ It is well known that among non-English-speaking immigrants, unemployment is a far greater problem for recent arrivals than for other groups [see, for example, Inglis and Stromback (1986)].
} 
These analyses therefore confirm that the labour force status of individuals in couple families is sensitive to the characteristics of the individual. The analyses also reveal a considerable degree of similarity between the labour market states of members of couple families. This similarity may result from assortative mating or economic incentives. While the various analyses presented are informative, they are also somewhat restrictive. Thus the range of ages considered in the tables is much wider than the 15-64 age brackets typically employed in labour market analysis. Moreover, the unemployment experience of children cannot be linked to that of parents, and this is a potential limitation of any study that has a focus on the burden of unemployment on the family unit. Given the shortcomings associated with analysis of the published data from the Labour Force Status and Other Characteristics of Families data set, the following section will analyse information from the 1991 Australian Census of Population and Housing.

\section{THE 1991 CENSUS AND THE INCIDENCE OF MULTIPLE UNEMPLOYED IN FAMILY UNITS}

As well as being concentrated in particular family units, the unemployed are concentrated in family units where there are not any employed members. This will have important implications where employment opportunities arise predominately through family contacts.

The 1991 Census Household Sample File is a one per cent sample of households in occupied private dwellings and a one per cent sample of persons in non-private dwellings. Information on each person in the private dwellings selected is contained in the sample file. Three levels of information are available: on the dwelling; on the family; and on the individual. These data are under-utilised in labour market research in Australia, and a description of the salient features is provided below.

The data are presented in a hierarchical structured file which permits the information on all members of a family to be linked. For example, the education levels of spouses can be linked to

Hence it would be expected that the pattern described here would be even more pronounced for immigrants who have lived in Australia for only a short period of time. 
examine the degree of assortative mating. The language characteristics of adults and children in a family can be linked to provide a focus on language-use patterns in the family. And the labour force status of family members can be linked to facilitate study of the concentration of the burden of unemployment.

The Census data on families are classified as follows. The numbers in parentheses give the percentage distribution of the 67,092 families represented in the Household Sample File.

\section{$\underline{\text { One Parent Families }}(8.2)$}

1. With dependent offspring only (4.4)

2. With dependent offspring and other related individuals only (0.4)

3. With other offspring only (2.4)

4. With other offspring and other related individuals only $(0.1)$

5. With dependent and other offspring only (0.8)

6. With dependent and other offspring and other related individuals (0.1)

\section{Couple Families $(54.7)$}

7. Couple only (19.8)

8. Couple and other related individuals only (0.6)

9. Couple with dependent offspring only (23.4)

10. Couple with dependent offspring and related individuals only (0.9)

11. Couple with other offspring only

12. Couple with other offspring and other related individuals only (0.2)

13. Couple with dependent and other offspring only

14. Couple with dependent and other offspring and other related individuals

Other Groups (37.2)

15. Family of related individuals only (1.2)

16. Not applicable (36.0) 
The not applicable category includes individuals classified as 'non-family members', 'group household members', 'lone person household members', and 'visitors' (see Australian Bureau of Statistics, 1994b).

While couple families constitute around 55 per cent of all families, they account for close to 70 per cent of the total population and 60 per cent of all unemployment. In comparison, lone parent families comprise 8 per cent of all families, 8 per cent of the total population and 13 per cent of all unemployment. The remaining family types categorised by the Census account for 37 per cent of all family groups, 24 per cent of the total population and 28 per cent of all unemployment. These data reveal, therefore, that a focus on couple families captures the majority of the unemployed and serves as a useful starting point for study of the distribution of the burden of unemployment on family units.

In the first instance the consistency of the data obtained from the 1991 Census Household Sample File and the Labour Force Status and Other Characteristics of Families was examined. A cross-tabulation of the labour market states of spouses in couple families for individuals aged 15 or more years was prepared from each data set for 1991. The most obvious difference between the distributions was in relation to the split between part-time and full-time work. However, this is expected given the different definitions in the two data sets. In the Census data the part-time / fulltime distinction is implemented using the information on the number of hours actually worked in the main job held in the reference week. Individuals reporting 35 or more hours were categorised as fulltime; those reporting fewer than 35 hours were categorised as part-time. In comparison, full-time workers in the Labour Force Survey are defined as employed persons who usually worked 35 hours or more per week in all jobs and other workers who, although usually working fewer than 35 hours a week, worked 35 or more hours during the reference week. Part-time workers are those who usually worked fewer than 35 hours per week and who did so during the reference week. Hence it is apparent that the Census will yield a higher count for part-time workers than the Labour Force Survey and, conversely, it will yield a lower count for full-time workers than the Labour Force Survey. 
A second difference between the two sets of data relates to the total number of families, which is considerably lower in the Census count. This is due to the exclusion of the 'not-stated' categories $^{8}$ included in the Census count (see Australian Bureau of Statistics, 1994a) and the focus in the analysis of the Census data on couples where the spouses were both present on Census night.

A third difference is that the number of unemployed in the Census exceeds that in the Labour Force Survey by nine per cent (Australian Bureau of Statistics, 1994a). This may be due to the underreporting of jobs involving only a few hours in the self-enumerated Census compared with the interview-based Labour Force Survey. Such an occurrence might reasonably be expected to lead to greater similarity of labour market outcomes.

Table 5 lists data from the 1991 Census that are relevant to the case where the husband and wife are both aged between 15 and 64. While the tables presented previously have included individuals aged 65 and over who are largely non-participants, the major difference between the findings in this section and those in the previous section are not due to differences in the age groups covered. Rather they are implications of the fundamental differences between the data sets noted above.

According to the Table 5 data, one in nine couple families has at least one spouse unemployed. One in 46 has both spouses unemployed. One-third of the total unemployment for couple families is concentrated in those families where both spouses are unemployed. Thus, study of the concentration of unemployment in particular couple families using the Census data leads to the conclusion that this is more intense than that reported on the basis of examination of the Labour Force Status and Other Characteristics of Families data base.

\footnotetext{
${ }^{8}$ Responses that are candidates for a 'not-stated' category in the Labour Force Survey are treated as sample loss and accounted for by weighting.
} 
Table 5: Couple Families Where Each Spouse is Aged 15-64: Labour Force Status of Husband and Wife, 1991, Numbers ('000 families) and Per cent Distribution

\begin{tabular}{|c|c|c|c|c|c|c|}
\hline $\begin{array}{c}\text { Wife } \\
\text { Husband }\end{array}$ & $\begin{array}{l}\text { Employed } \\
\text { Full time }\end{array}$ & $\begin{array}{l}\text { Employed } \\
\text { Part time }\end{array}$ & Unemployed & $\begin{array}{l}\text { Not in the } \\
\text { labour force }\end{array}$ & $\begin{array}{l}\text { All labour } \\
\text { force states }\end{array}$ & $\begin{array}{c}\text { Wife's } \\
\text { Unemploy. } \\
\text { rate }\end{array}$ \\
\hline $\begin{array}{l}\text { Employed } \\
\text { Full time }\end{array}$ & $37.7 \%$ & $30.5 \%$ & $2.8 \%$ & $29.1 \%$ & $\begin{array}{c}100 \% \\
2024.5\end{array}$ & $3.9 \%$ \\
\hline $\begin{array}{l}\text { Employed } \\
\text { Part time }\end{array}$ & $22.0 \%$ & $44.7 \%$ & $3.1 \%$ & $30.2 \%$ & $\begin{array}{l}100 \% \\
258.2\end{array}$ & $4.5 \%$ \\
\hline Unemployed & $12.9 \%$ & $11.5 \%$ & $26.1 \%$ & $49.6 \%$ & $\begin{array}{l}100 \% \\
231.9\end{array}$ & $51.7 \%$ \\
\hline $\begin{array}{l}\text { Not in the } \\
\text { labour force }\end{array}$ & $11.2 \%$ & $9.8 \%$ & $1.9 \%$ & $77.1 \%$ & $\begin{array}{l}100 \% \\
268.5\end{array}$ & $8.3 \%$ \\
\hline $\begin{array}{l}\text { All labour } \\
\text { force states }\end{array}$ & $\begin{array}{l}31.6 \% \\
878.8\end{array}$ & $\begin{array}{l}28.2 \% \\
785.4\end{array}$ & $\begin{array}{l}4.7 \% \\
129.8\end{array}$ & $\begin{array}{l}35.5 \% \\
989.1\end{array}$ & $\begin{array}{l}100 \% \\
2783.1\end{array}$ & $7.2 \%$ \\
\hline $\begin{array}{c}\text { Husband's } \\
\text { Unemploy. } \\
\text { rate }\end{array}$ & $3.5 \%$ & $3.5 \%$ & $48.4 \%$ & $14.7 \%$ & $9.2 \%$ & \\
\hline
\end{tabular}

Source: 1991 Census: Household Sample File

An advantage of using the 1991 Census data is that it allows an analysis of the concentration of the burden of unemployment in couple families with well-defined characteristics. For example, all couple families where each spouse is an early school leaver can be studied separately. Data for this sub-set of the population are presented in Table 6.

The most interesting aspect of these data from the perspective of the family unit is that there does not appear to be a greater concentration of the burden of unemployment in particular couple families among early school leaver families. Hence, according to the Table 6 data, one in eight of the couple families that are among the least educated in society has at least one spouse unemployed. One in 45 has both spouses unemployed. One-third of the total unemployment for this group is concentrated in couple families where both spouses are unemployed. These summary statistics are only slightly inferior to the Table 5 data that covers all education levels. Thus, while the unemployment rate for early school leaver males is almost three percentage points higher than the overall average, and that for early school leaver females one-half of one percentage point higher than 
the overall average, this inferior employment situation of the individual does not translate into a poorer unemployment situation for couple families. This situation appears to arise due to the lower level of labour force participation of both male and female early school leavers, at all labour market states of their partners.

Table 6: Early School Leaver Couple Families Where Each Spouse is Aged 15-64: Labour Force Status of Husband and Wife, 1991, Numbers ('000 families) and Per cent Distribution

\begin{tabular}{|c|c|c|c|c|c|c|}
\hline Wife & $\begin{array}{c}\text { Employed } \\
\text { Full time }\end{array}$ & $\begin{array}{c}\text { Employed } \\
\text { Part time }\end{array}$ & Unemployed & $\begin{array}{c}\text { Not in the } \\
\text { labour force }\end{array}$ & $\begin{array}{c}\text { All labour } \\
\text { force states }\end{array}$ & $\begin{array}{c}\text { Wife's } \\
\text { Unemploy. } \\
\text { rate }\end{array}$ \\
\hline $\begin{array}{c}\text { Employed } \\
\text { Full time }\end{array}$ & $33.6 \%$ & $28.4 \%$ & $2.6 \%$ & $35.4 \%$ & $\begin{array}{c}100 \% \\
461.4\end{array}$ & $4.0 \%$ \\
\hline $\begin{array}{c}\text { Employed } \\
\text { Part time }\end{array}$ & $15.3 \%$ & $45.0 \%$ & $2.0 \%$ & $37.7 \%$ & $\begin{array}{c}100 \% \\
65.3\end{array}$ & $3.2 \%$ \\
\hline Unemployed & $8.0 \%$ & $9.4 \%$ & $22.5 \%$ & $60.1 \%$ & $100 \%$ & $56.3 \%$ \\
\hline $\begin{array}{c}\text { Not in the } \\
\text { labour force }\end{array}$ & $5.9 \%$ & $8.5 \%$ & $0.7 \%$ & $84.9 \%$ & $100 \%$ & $4.7 \%$ \\
\hline $\begin{array}{c}\text { All labour } \\
\text { force states }\end{array}$ & $24.7 \%$ & $24.6 \%$ & $4.2 \%$ & $46.6 \%$ & $100 \%$ & $7.8 \%$ \\
\hline $\begin{array}{c}\text { Husband's } \\
\text { Unemploy. } \\
\text { rate }\end{array}$ & $3.3 \%$ & $4.0 \%$ & $55.0 \%$ & $18.6 \%$ & $11.9 \%$ & \\
\hline
\end{tabular}

Source: 1991 Census: Household Sample File

A further advantage of the Census data is that they allow information on the unemployment status of family members other than the husband and wife to be analysed. There are 27,575 couple families in the Census Sample that have complete information on the labour force status of all family members. The number of family members unemployed ranges from 0 to 5 . Relevant details are listed in Table 7.

It is apparent from the Table 7 data that the overwhelming majority ( 85.3 per cent) of couple families do not have any family members in the state of unemployment. 11.5 per cent have one family member unemployed while a minority have two or more family members unemployed. In terms of the 
distribution of the pool of unemployment, 63 per cent is in families where there is only one family member unemployed, 29 per cent is in families where two family members are unemployed and 8 per cent in families where three or more members are unemployed.

Table 7: Distribution of Couple Families by Number of Family Members Unemployed, Ages 15-64, 1991

\begin{tabular}{|c|c|c|}
\hline Number Unemployed & Percentage Distribution & $\begin{array}{c}\text { Percentage Share of } \\
\text { Unemployment }\end{array}$ \\
\hline 0 & 85.3 & 0.0 \\
\hline 1 & 11.5 & 63.0 \\
\hline 2 & 2.7 & 29.2 \\
\hline 3 & 0.3 & 1.8 \\
\hline 4 & 0.1 & 0.4 \\
\hline 5 & 0.0 & \\
\hline
\end{tabular}

Source: 1991 Census: Household Sample File

One family in 32 , therefore, has two or more family members unemployed, and they account for 37 per cent of all unemployment in couple families. As the burden of unemployment for this group of families appears to be relatively great, they provide an appropriate focus for unemployment reducing policies.

It is also interesting to enquire a little further into the nature of the couple families with multiple members unemployed. To this end Table 8 lists data on the distribution of the number in the family unemployed by the number of family members participating in the labour force.

The interesting feature of Table 8 is the preponderance of cases where individuals are members of couple families with multiple members unemployed and no member employed. Thus, among individuals from families where two members are unemployed, 75 per cent do not have any family members employed. This is a statistic of major importance where job information is obtained through indirect channels of family members. Among individuals from families where three members 
are unemployed, 67 per cent do not have any family members employed. For individuals from families with four or five members unemployed, around three-quarters are from families where no family member is employed. Even where there is only one family member unemployed, in only two cases in three is there a family member in employment. Hence, these data add another dimension to the unemployment problem: not only is there a concentration of the burden of unemployment in particular couple families, but the unemployed also tend to be concentrated in couple families where there are not any employed members. This will have obvious important implications where employment opportunities arise predominately through family contacts.

Table 8: Distribution of Number in Couple Families Unemployed by Number Participating in the Labour Force, Ages 15-64, Per cent Distribution and Numbers ('000 families), 1991

\begin{tabular}{|c|c|c|c|c|c|c|}
\hline \multirow{2}{*}{$\begin{array}{l}\text { Number in the } \\
\text { Labour Force }\end{array}$} & \multicolumn{6}{|c|}{ Number Unemployed } \\
\hline & 0 & 1 & 2 & 3 & 4 & 5 \\
\hline 1 & 27.1 & 34.8 & - & - & - & - \\
\hline 2 & 58.2 & 39.4 & 74.9 & - & - & - \\
\hline 3 & 10.6 & 17.9 & 14.1 & 67.4 & - & - \\
\hline 4 & 3.6 & 6.4 & 8.4 & 24.2 & 73.9 & - \\
\hline 5 & 0.5 & 1.2 & 2.2 & 7.4 & 17.4 & 75.0 \\
\hline 6 & 0.1 & 0.3 & 0.4 & - & 4.3 & 25.0 \\
\hline 7 & - & - & - & 1.1 & 4.3 & - \\
\hline $\begin{array}{c}\text { Total } \\
(\%)\end{array}$ & 100.0 & 100.0 & 100.0 & 100.0 & 100.0 & 100.0 \\
\hline $\begin{array}{c}\text { Number } \\
\text { ('000) }\end{array}$ & 2197.0 & 318.4 & 73.7 & 9.5 & 2.3 & 0.4 \\
\hline
\end{tabular}

Source: 1991 Census: Household Sample File

\section{CONCLUSION}

The most commonly cited index of "the unemployment problem" is the male unemployment rate. In 1994 this was 9.9 per cent. While this might provide an appropriate indication of the stage of 
the business cycle, it may not be the best measure of the economic and social impact associated with any particular level of unemployment. It has been shown in this paper that a given male unemployment rate can be associated with quite different burdens of unemployment in couple families. For example, in both 1982 and 1989 the male unemployment rate was around 5.5 per cent. In 1982, 11 per cent of the total unemployment in couple families was experienced in families where both husband and wife were unemployed. In comparison, in 198918 per cent of unemployment was experienced in couple families where both husband and wife were unemployed. One couple family in every 385 had both spouses unemployed in 1982. In 1989, the comparison figure was one in every 215 couple families.

The analyses presented show that the burden of unemployment in couple families differs according to the characteristics of the family. It is particularly intense in couple families with young dependants, and among immigrants from non-English-speaking countries. There are also groups where the degree of unemployment among individuals is relatively high. However, it does not follow that there is a close association between groups for whom the conventional measure of unemployment is high and groups for whom the burden of unemployment as measured here is high. In the case of early school leavers, for example, the conventional unemployment rate is quite high while the burden of unemployment does not appear to be disproportionate.

The analyses also show that the description of the labour market is sensitive to the data source. Study of the 1991 Census of Population and Housing, where labour market status is selfenumerated, suggests that there is a much closer association between the labour market states of partners in couple families. This results in a greater concentration of unemployment in family units.

It is also shown in this paper that there are many families where there are multiple family members unemployed and no member employed. It was argued that this will have important implications where knowledge of employment opportunities is obtained primarily through family contacts. 
Why is there such a concentration of the burden of unemployment in particular family units? Among the possible explanations are regional factors, assortative mating and the impact of the income support system. Regional variations in labour demand may provide an explanation for the phenomena described in this paper. In this regard the recent research by Gregory and Hunter (1996) is informative. They show that there is a rigidity in the spatial concentration of job location that is important to the understanding of employment inequality. Another explanation may be assortative mating which results in a strong association between the observed (e.g., educational attainment) and unobserved characteristics of husbands and wives. Our study of the situation for early school leavers suggests that to the extent that the assortative mating explanation is valid, it must have a stronger basis in unobservable characteristics than in the observable characteristics. If this is the case, then the observations on family members can be used in fixed effects models to examine unemployment outcomes.

A further explanation is that the concentration of the burden of unemployment on the family is the product of the design of the social security system and the complementarity of spouses' leisure times. The dependency based payments for the spouse of an unemployment benefit (Job Search Allowance, New Start Allowance) recipient will discourage employment and encourage unemployment or non-participation. Similarly, the requirement for married couples without dependent children to qualify for income support in their own right (rather than as a dependent spouse) will tend to result in lower levels of non-participation and possibly higher levels of unemployment among the spouses of the unemployed. These factors have been studied by Bradbury (1993), Department of Social Security (1994), among others. These studies raise doubts over whether the social security system has created strong incentives for people to choose unemployment over work. King et al. (1995, p. 18) note the "apparent greater importance of labour market disadvantage than of disincentives related to social security provisions'. The observable and unobservable characteristics that lead to such labour market disadvantage provide an appropriate focus for future research.

A number of other issues that require research have been identified in this paper. Among these are the links between regional inequality in job loss and the concentration of unemployment in 
family units. The dimensions of any ghettos of economic hopelessness that the economy may be creating need to be determined. And while preliminary statistics on the labour market status of family members other than the husband and wife have been presented, further enquiry into these data are needed. The extent of inter-generational transmission of inequality and the extent to which related unemployed individuals live together need to be quantified. 


\section{REFERENCES}

Australian Bureau of Statistics, (1994a). ‘1991 Census Data Quality: Labour Force Status', Australian Bureau of Statistics Census Working Paper 94/1.

Australian Bureau of Statistics, (1994b). 1991 Census of Population and Housing Household Sample File [computer file]. Canberra: Australian Bureau of Statistics.

Borland, Jeff and Roger Wilkins, (1996). 'Earnings Inequality in Australia', Economic Record, Vol. 72, No. 216, pp. 7-23.

Bradbury, Bruce, Pauline Grade and Joan Vipond, (1986). 'Youth Unemployment and Intergenerational Immobility', Journal of Industrial Relations, Vol. 28, No. 2, pp. 191-210.

Bradbury, Bruce, (1993). 'Family Assistance, Replacement Rates and the Unemployment of Married Men', Australian Bulletin of Labour, Vol. 19, No. 2, pp. 114-132.

Bureau of Labour Market Research, (1986). The First Wave of the Australian Longitudinal Survey: Facts and Figures About Young CES Registrants, Monograph Series No. 12, Canberra: Australian Government Publishing Service.

Department of Social Security, (1994). Does the Social Security Income Support System Remove the Incentive to Work?, Policy Discussion Paper No. 4, February, Canberra: Australian Government Publishing Service.

Gregory, Bob and Boyd Hunter, (1995). 'The Macro Economy and the Growth of Ghettos and Urban Poverty in Australia', Centre for Economic Policy Research Discussion Paper No. 325, Australian National University.

Gregory, Bob and Boyd Hunter, (1996). 'Increasing Regional Inequality and the Decline of Manufacturing', in Dialogues on Australia's Future, edited by Peter Sheehan, Bhajan Grewal and Margarita Kumnick, pp. 307-324, Melbourne: Centre for Strategic Economic Studies, Victoria University.

Harding, Ann, (1996). 'Recent Trends in Income Inequality in Australia', in Dialogues on Australia's Future, edited by Peter Sheehan, Bhajan Grewal and Margarita Kumnick, pp. 283-305, Melbourne: Centre for Strategic Economic Studies, Victoria University.

Inglis, Paul A. and Thorsten Stromback, (1986). 'Migrants' Unemployment: The Determinants of Employment Success', Economic Record, Vol. 62, No. 178, pp. 210-324.

King, Anthony, Bruce Bradbury and Marilyn McHugh, (1995). 'Why Do the Wives of Unemployed Men Have Such Low Employment Rates?', Reports and Proceedings No. 125, Social Policy Research Centre, The University of New South Wales.

Miller, Paul and Paul Volker, (1987). 'The Youth Labour Market in Australia: A Survey of Issues and Evidence', Centre for Economic Policy Research Discussion Paper No. 171, May, The Australian National University.

Russell, Bill and Warren Tease, (1991). 'Employment, Output and Real Wages', Economic Record, Vol. 67, No. 196, pp. 34-45. 